\title{
Bringing the former president of Chad H. Habré to justice and the Extraordinary African Chambers
}

\author{
I. S. Marusin \\ Saint-Petersburg State University, \\ 7-9, Universitetskaya nab., St. Petersburg, 199034, Russian Federation
}

For citation: Marusin, Igor S. 2019. "Bringing the former president of Chad H. Habré to justice and the Extraordinary African Chambers". Vestnik of Saint Petersburg University. Law 4: 691-698. https://doi.org/10.21638/spbu14.2019.405

\begin{abstract}
Hissène Habré seized power in Chad as a result of long civil war in 1982 and organized largescale repressions of his political enemies during his rule. In 1990, he was deposed by a military coup and fled to Senegal, where he got asylum. This paper discusses the institutional aspects of the legal prosecution of $\mathrm{H}$. Habré, which began in 2003 when proceedings against him were instituted in Belgium, and analyzes the Judgment of the UN International Court of Justice in the case of Belgium v. Senegal of 2012. Much attention is paid to the special international court - the Extraordinary African Chambers in the Senegalese legal system that were established by the Agreement between the African Union and Senegal in 2012 to investigate international crimes committed on the territory of Chad from 1982 to 1990 . This paper analyzes the structure of the Extraordinary African Chambers and their jurisdiction. In 2016, the Extraordinary African Chambers sentenced H. Habré to life imprisonment, and this verdict came into force in 2017. According to the author's opinion, the trial of H. Habré has important political and juridical meaning. A politician, who had come to power with the help of the United States and other Western countries and who had been their strong ally during his rule, protecting their interests in Central Africa, was brought to justice.

Keywords: international criminal law, international courts, international crimes, United Nations International Court of Justice, African Union, responsibility of heads of state.
\end{abstract}

1. Introduction. The former President of the Republic of Chad Hissène Habré, who had lived in Senegal for more than ten years already, was arrested on June 30, 2013 in Dakar, the capital city of Senegal. Thus how the final stage of the long and complex political and legal process of bringing to justice one the most odious African politicians of the last century was launched. This paper discusses the institutional and legal aspects of the proceedings.

Hissène Habré was born in 1942 in Faya-Largeau, a settlement in French Equatorial Africa, which after the disintegration of the French colonial empire became a part of another state - the Republic of Chad. He completed a university degree in France, and after he finished his studies in 1971, he came back to his native country. At that time, Chad became the scene of a fierce struggle between various political groups. The state of affairs was complicated because foreign states interfered into that struggle - one of the opposing sides was supported by the Libyan government and the other was supported by the French and United States governments. H. Habré originally joined pro-Libyan forces but later the

(C) Санкт-Петербургский государственный университет, 2019 
Armed Forces of the North (FAN), a military and political organization under his command, sided with the opponents of the pro-Libyan forces. As a result of the armed conflict, FAN that had considerable military aid and economic assistance from the United States and France, occupied the capital city of Chad, N'Djamena, on June 7, 1982, and H. Habré became the head of state.

After seizing power H. Habré and his government organized large-scale repressions of their political enemies. It's difficult to establish the exact number of victims, but according to assessments by human rights organizations, the total number of murdered, missing and tortured people was from 12000 to 40000 . However, neither the governments of Western states, nor Western mass media paid any attention to crimes committed by H. Habrés regime in the 1980s. In 1983, the armed conflict between Chad and Libya began because of contested territories, and it's clear that during this conflict H. Habré was fully supported by the United States and French governments.

By 1988, Libya withdrew its troops from the contested territories, however, notwithstanding the victory, H. Habrés regime was rather weak. He did not manage to improve the economic situation in the country and reconcile various ethnic groups inhabiting Chad. In 1990, the opposition forces launched their advance to N'Djamena. H. Habrés armed forces were defeated, Western countries refused to help him, and the capital city of Chad was taken by rebels under the command of Idriss Déby on December 2, 1990. H. Habré fled from the country, soon got asylum in Senegal and settled there. (For more details about H. Habrés political career and his acts as the President see: Sall 2013; Amoulgam 2015.)

It seemed that $\mathrm{H}$. Habré withdrew from political struggle forever like other deposed and dethroned African leaders, e.g. the former Emperor of the Central African Empire (now Central African Republic) Bokassa I, or the President of Zaire (now the Democratic Republic of the Congo) for many years Mobutu Sese Seko Kuku Ngbendu wa za Banga, but ten years later he had to return and not on his own free will.

2. The main research. In January, 2000, seven residents of Chad applied to the Senegalese law enforcement bodies demanding to investigate abuses by H.Habré in the time of his being in power. The investigation was instituted, however, it was ceased in July of the same year by the decision of the Dakar Court of Appeals. The court ruled that the Senegalese law enforcement bodies' jurisdiction did not cover crimes committed by a foreign national on the territory of a foreign state. However, this decision could not stop the launched case. In November, 2000, a Belgian national born in Chad used the Belgian law on universal jurisdiction of June 16,1993, which allowed to claim criminal jurisdiction over all serious violations of the international humanitarian law, regardless of the place where the crime was committed, the nationality and country of residence of the accused. That individual applied to the law enforcement bodies of Belgium, demanding to prosecute H.Habré in accordance with the said law. Over the next, 2001 year, 16 residents of Chad and two individuals with double Chadian and Belgian citizenship filed similar applications. (Actually, the proceedings referred to H.Habrés prosecution up to 2012 are presented by the Judgment of the UN International Court of Justice on Belgium's case v. Senegal of July 20,2012, paragraphs 15-37. This Judgment is posted on the official website of the International Court of Justice in English and in French www.icj-cji.org, accessed on January 20, 2018.)

The Belgian law enforcement bodies instituted investigation of abuses by H. Habré based on the said applications, and asked the law enforcement bodies of Chad and Senegal 
for assistance. The Chadian law enforcement bodies willingly cooperated with their Belgian colleagues and provided them with a lot of materials certifying crimes committed by H. Habré. The Chadian Minister of Justice also informed in October, 2002 that H. Habrés immunity of heads of state had already been waived in 1993.

As a result of the investigation, in September, 2015, Belgium issued an international arrest warrant against $\mathrm{H}$. Habré accused of committing and being an accomplice of such serious violations of the international humanitarian law as tortures, genocide, crimes against humanity and war crimes. This order was sent to Senegal but in November, 2005 the Dakar Court of Appeals refused to execute the court order, pointing out that it had no right to determine the lawfulness of bringing H. Habré to justice in Belgium, taking into account his status of a former head of state and those immunities he should have. On the next day after this decision was taken, Senegal passed over the issue of H. Habrés prosecution to be investigated by the African Union - regional international organization uniting African states, the goals of which are their political and economic cooperation as well as assistance to them in solving international disputes. (For more details about this organization see: Ivanenko 2003; Barkov 2003; Morgun 2016). In July, 2006, the Assembly of Heads of State and Government of the African Union acknowledged the issue of H. Habré to be within its competence and authorized the Chairman of the Union to provide the required assistance to Senegal in holding a fair trial of H. Habré.

Over the next several years, Belgium addressed the government of Senegal several times via diplomatic channels demanding either to start legal proceedings or to turn H. Habré over to Belgium. Various international organizations also demanded the same from Senegal. Yielding to pressure, Senegal introduced some meaningful supplements to its criminal law, including genocide, was crimes, crimes against humanity and other serious violations of the international humanitarian law, as well as gave the right to Senegalese law enforcement bodies to hold foreign nationals liable if they committed the said crimes outside the territory of Senegal but being under Senegalese jurisdiction at the moment. And what is more, an amendment to the Constitution of Senegal was introduced in 2008, according to which the criminal law setting forth or toughening the punishment, adopted after the crime was committed, can be applied to persons charged with serious violations of the international humanitarian law, as an exception from the general principles.

Thus, in 2008, the required legal grounds were established in Senegal to charge H. Habré, but the Senegalese law enforcement bodies still did not take legal action against the former President of Chad, referring to the lack of finances to arrange and hold such a trial $^{1}$. Then in February, 2009, the Belgium government applied to the UN International Court of Justice demanding to recognize the fact of Senegal violating the country's international commitments, according to which this state was to either take H. Habré to court in Senegal or turn him over to Belgium. This Senegal's commitment was substantiated by references to the customary humanitarian law and the UN Convention against Torture and Other Cruel, Inhuman or Degrading Treatment or Punishment of December 10, 1984 (Kolosov, Krivchikova (comp.) 1996, vol. 3, 38-50).

${ }^{1}$ In November, 2010, the meeting of representatives of states and international organizations took place in Dakar to discuss the problem of trying H. Habré in court. As a result, the donor states took upon themselves the responsibility to allot Euro $8,6 \mathrm{mln}$ to Senegal for these purposes, with Belgium allotting $1 \mathrm{mln}$. 
The UN International Court of Justice took the decision in that case on June 20, 2012. Belgium's demands, based on the provisions of the customary international humanitarian law, were not investigated by the Court per se, stating in paragraph 55 of the Judgment that at the moment the case was made, there was no dispute between the parties as to application of these provisions, and because of that the issue of the customary international law's making a state to prosecute a foreign national, who had seriously violated the international humanitarian law outside the borders of that state, are not under the jurisdiction of the International Court of Justice when investigating this case.

Thus, when assessing the reasonableness of Belgium's demands, the International Court of Justice based on the analysis of just one international agreement, to wit, the UN Convention against Torture and Other Cruel, Inhuman or Degrading Treatment or Punishment of December 10, 1984. (For more details about it see: Yakovlev 1998.) This Convention came into force for Senegal in 1987, and for Belgium in 1999. After investigating the facts of the case, the International Court of Justice came to the conclusion that Senegal had not fulfilled two of the country's commitments following from this Convention.

The first of the commitments is set forth in Article 6, paragraph 2 of the Convention, according to which the State party in whose territory a person alleged to have participated in tortures was found, shall immediately make a preliminary inquiry into the facts and investigate the actions of this person. The International Court of Justice stated in paragraph 85 of its Judgment on the case that in the course of investigation Senegal had not provided the Court with any evidence that such preliminary enquiry had been made in case of H. Habré.

The second commitment not fulfilled by Senegal in the opinion of the International Court of Justice is set forth in Article 7, paragraph 1 of the Convention. According to it, "the State party in the territory under whose jurisdiction a person alleged to have committed" tortures "is found shall... if it does not extradite him, submit the case to its competent authorities for the purpose of prosecution". As Senegal had done neither by the time the case was investigated, the International Court of Justice found Senegal violating the state's commitments according to that agreement in paragraph 107 of its Judgment. The Court stated in paragraph 112 that Senegal's referring to financial difficulties when arranging prosecution of H. Habré could not justify Senegal's failure to fulfill international commitments.

At the same time it is said in paragraphs 100 and 101 of the Judgment that Senegal was obliged to apply the provision from Article 7 of the Convention against Torture to actions committed by H. Habré after Senegal ratified the Convention, i. e. after June 26, 1987. Senegal had no such obligation in case of actions committed by H. Habré before the said date.

It seems that thus the International Court of Justice indirectly answered the question which it avoided to answer directly in paragraph 55 of the Judgment, to wit, if there is a provision of the customary international law now, according to which a state is to prosecute a foreign national who seriously violated the international humanitarian law outside the borders of that state. It follows from paragraphs 100 and 101 of the Judgment that there is no such provision, otherwise the date of the Convention's coming into force for Senegal in 1984 and the very fact of the state's participation in this Convention would be senseless. 
The Judgment of the International Court of Justice of July 20, 2012 finding Senegal the violator of the country's international commitments, strengthened international pressure on the authorities of this country even more and made them finally determine the further fate of the former President of Chad staying on their territory. Three main variants of H.Habrés prosecution were reviewed: 1) prosecution by Senegalese law enforcement bodies; 2) extradition to Chad; 3) establishment of a new international law court. And after fairly long deliberations the leaders of Senegal chose the latter variant.

This decision seems the most appropriate. Had H. Habré been tried by a Senegalese court, this could not but bring about the feeling of the state's sovereignty limitation in the Chadian residents. In that case the former President of Chad was to answer to a court of a foreign state for his crimes committed against residents of Chad on the territory of Chad, and the said foreign state would have thus expanded its jurisdiction, i.e. its authority over the territory of Chad. The reaction of Chadian residents could have been even more negative in case H. Habré was tried in Belgium, the state on another continent and besides the one that had colonies in Africa for a long time. However, a possibility of a just and unbiased trial of H. Habré if Chad, where he had already been twice sentenced to capital punishment in absentia, was very doubtful, taking into account the fact that Idriss Déby, who had removed H. Habré from power as a result of the military coup, was still in power there.

Investigation of $\mathrm{H}$. Habrés case in an international court of law allowed to avoid the above said negative consequences. In contrast to exercise of jurisdiction by another state, exercise of jurisdiction by an international court of law can be considered a limitation of state's sovereignty to a much lesser extent. At the same time, participation of foreign judges in the trial allows to increase independence and impartiality in investigation.

On August 22, 2012, the Government of Senegal and the African Union Commission signed the Agreement on establishment of the Extraordinary African Chambers as a part of the Senegalese court system to try international crimes committed in Chad from June 7, 1982 to December 1, 1990 (posted on the Extraordinary African Chambers official website: Accord entre le gouvernement de la Republique de Senegal et l'Union Africaine sur la creation de Chambres africaines extraordinaires au sein de la jurisdictions senegalaises. Available at: www.chambresafricaines.org/pdf/accord\%20UA-Senegal\%chambres\%20africa (accessed January 20, 2018)). The Statute of the Extraordinary African Chambers is in the annex to the said Agreement (also posted there: Statut des Chambres africaines extraordinaires au sein de la jurisdictions senegalaises pour la poursuite des crimes internationaux commis au Tchad Durant le period du 7 juin 1982 au 1 decembre 1990. Available at: www.chambresafricaines.org/pdf/accord\%20UA-Senegal\%chambres\%20africa (accessed January 20, 2018)).

According to this Agreement, the new four-section structure was established as a part of the Senegalese court system. It consisted of one Extraordinary African Investigative Chamber within the Tribunal Régional Hors Classe de Dakar (Regional Court of Dakar), one Extraordinary African Indicting Chamber with the Dakar Court of Appeals, one Extraordinary African Trial Chamber with the Dakar Court of Appeals and one Extraordinary African Appeals Chamber attached to the Dakar Court of Appeals. The task of the Investigative Chamber was preliminary investigation and preparation of the indictment. The Indicting Chamber supervised preliminary investigation and approved the indictment. The Trial Chamber investigated the case per se, and the Appeals Chamber examined complaints about verdicts. 
According to Article 11 of the Statute, the Extraordinary African Investigative Chamber within the Tribunal Régional Hors Classe de Dakar was composed of the four main investigative judges and two alternate investigative judges of Senegalese nationality. The Indicting Chamber was composed of three main judges and one alternate judge of Senegalese nationality, the Trial Chamber was composed of two main judges and two alternate judges of Senegalese nationality and the President, a non-Senegalese judge from another African Union member state. The Appeals Chamber was composed of two main judges and two alternate judges of Senegalese nationality and also the President of the Chamber from another African Union member state.

The judges were nominated by the Senegalese Minister of Justice and appointed by the Chairperson of the African Union Commission. Only individuals who exercised judicial functions for a period of at least ten years could be nominated.

Besides, there was the Chief Prosecutor and three deputy prosecutors of Senegalese nationality in the Extraordinary African Chambers. They were appointed as the judges, and the Secretary of the Chambers was appointed by the Senegalese Minister of Justice.

Article 15 of the Statute provided for a special office of the Administrator of the Extraordinary African Chambers. His/her task was non-judicial aspects of the administration and servicing the Chamber's operation, including maintaining relations with the donor states and other states, cooperation with which was required for performance of the tasks set for the Extraordinary African Chambers.

According to Article 6 of the Agreement, all judges of the Extraordinary African Chambers of non-Senegalese nationality as well as members of their families enjoyed the privileges and immunities accorded to diplomatic agents in accordance with the $1961 \mathrm{Vi}$ enna Convention on Diplomatic Relations. Senegalese judges, prosecutors, the Administrator and other personnel of the Extraordinary African Chambers enjoyed immunities and privileges in accordance with the 1965 General Convention on the Privileges and Immunities of the Organization of African Unity, including immunity from criminal and civil prosecution for all acts performed in their official capacity as well as exemption from taxation on all incomes received for their service in the Extraordinary African Chambers.

Article 7 of the Agreement sets forth the immunities and privileges enjoyed by counsel for the defense irrespective of nationality. In particular, they were given immunity from detention and arrest related to their performance as counsel for the defense; inviolability of all their documents and instruments used to perform their commitments; immunity from criminal and civil prosecution for all acts performed in their official capacity; exemption from all limitations on immigration when crossing the Senegalese borders. On the whole, the Government of Senegal took upon itself the commitment to provide protection and security of all participants of trials in the Extraordinary African Chambers according to Article 9.

The jurisdiction of the Extraordinary African Chambers is set forth in Article 3 of the Statute. According to it, the Extraordinary African Chambers have the power to prosecute and try the person or persons responsible for crimes and serious violations of the customary international law and international conventions ratified by Chad, and committed on the territory of Chad during the period from June 7, 1982 to December 1, 1990, i.e. the period when H. Habré was in power. At the same time, the Extraordinary African Chambers have the right to prosecute only the most serious crimes within their jurisdiction. 
Article 4 of the Statute contains the list of these crimes. They are genocide, crimes against humanity, war crimes and torture. According to Article 9, these crimes are not subject to any statutory limitations. One pays attention to tortures singled out as separate essential elements of the crime under the jurisdiction of the Extraordinary African Chambers. There is also responsibility for tortures in the Statutes of other international criminal courts, for example, the International Criminal Court (ICC) or the International Criminal Tribunal for Rwanda but as one of the variants of crimes against humanity or war crimes. Probably, singling our tortures as separate essential elements of the crime under the jurisdiction of the Extraordinary African Chambers is related to the already reviewed above Judgment of the UN International Court of Justice in the case Belgium v. Senegal of 2012. It was exactly the 1984 Convention against Torture and prohibited by it tortures that were pointed out as the only legal basis for foreign states claiming their jurisdiction in case of residents of Chad committing crimes on the territory of Chad.

According to Article 10 of the Statute, any person who committed, planned, ordered, or instigated others to commit the above said crimes or aided to execute a crime, is responsible for the crime. Article 10 also stipulates that the high official position of the person committing such crimes, whether the head of state or government, or a high-standing government official does not relieve him or her from criminal responsibility but on the contrary serves as an aggravating circumstance. Item 4 of this Article sets forth that commitment of any of such acts by a subordinate does not relieve his or her superior from criminal responsibility for such crimes if such a superior knew or had reason to know that a subordinate was about to commit such acts or did so, and the superior failed to take the necessary measures to prevent such acts or to punish the perpetrators thereof.

According to Article 19 of the Statute, no person can be tried before the Extraordinary African Chambers for the same crimes for which that person was convicted or acquitted by the Chambers before. At the same time, a person already convicted or acquitted by another court of law, can be tried by the Extraordinary African Chambers if the proceedings in the other court were for the purpose of shielding that person from criminal responsibility for committed acts, or investigation was conducted not impartially and justly enough and not provided the accused all guarantees for exercising his/her right to defense required by the international law. Article 20 of the Statute also stipulates that amnesty granted to any person falling within the jurisdiction of the Extraordinary African Chambers with respect to the above mentioned crimes, is not a bar to prosecution by the Chambers.

The Extraordinary African Chambers were to be governed in their operation first of all by their Statute as well as the Senegalese Criminal Code and the Code of Criminal Procedure. In case the defendant was found guilty, the Extraordinary African Chambers could impose the following sentences, penalties and sanctions: 1) imprisonment of maximum 30 years or life imprisonment; 2) a fine, the amount of which is determined under the criteria provided for by the Senegalese law; 3 ) a forfeiture of proceeds, property and assets derived from the crime.

To execute the Agreement on establishment of the Extraordinary African Chambers H. Habré was arrested on June 30, 2013. After preliminary investigation was completed, the trial in the Trial Chamber started on July 20, 2015 and ended in pronouncement Hissène Habré guilty on May 30, 2016. The former President of Chad was found guilty in committing crimes against humanity, war crimes and tortures and sentenced to life im- 
prisonment (posted on the Extraordinary African Chambers official website www.chambresafricaines.org/jugement_complet.pdf (accessed February 16, 2018)). This sentence was confirmed by the Appeals Chamber on April 27, 2017 and came into force (posted on the Extraordinary African Chambers official website www.chambresafricaines.org/pdf/ arret_integral.pdf (accessed February 16, 2018)).

3. Conclusions. That's how the trial of the former President of Chad Hissène Habré that lasted for more than 15 years ended. His being brought to justice has important political and juridical meaning. It is important from the political point of view that a politician, who had become the President with the help of the United States and other Western countries and who had been their strong ally during his rule, protecting their interests in Central Africa, was prosecuted. But when the correlation of political forces changed, the former support was terminated, and H. Habré had to answer for his actions. Thus, sentencing the former President of Chad certifies that a political union with the United States and pursuing a pro-Western policy does not necessarily guarantee release from responsibility for actions while pursuing this policy.

From the legal point of view, the case of H. Habre showed the importance of the principle of non-applicability of statutory limitations to war crimes, crimes against humanity and genocide. It was clearly showed that even if political factors in some period of time do not allow to prosecute individuals, who committed such crimes as it was in case of H. Habré in the last decade of the previous century, the threat of their being brought to justice in case the political environment changes, will be present till the end of their lives.

The establishment and performance of the Extraordinary African Chambers also showed the capability of African states and international organizations to independently set up an international criminal court and objectively investigate a case against a former head of state without the help of representatives of other continents, thinking themselves to be more developed. One would like to hope that the trial of Hissène Habré will not stay the only trial of this kind in the history of African justice.

\section{References}

Amoulgam, Aze Kerte. 2015. L’Affaire Hissène Habré. Paris, L'Harmattan.

Barkov, A. V. 2003. “The African Union”. Moskovskii zhurnal mezhdunarodnogo prava 3: 235-255. (In Russian)

Ivanenko, V.S. 2003. “The African Union”. Entsiklopediia mezhdunarodnykh organizatsii. Vol 1, ed. by L. N. Galenskaia and S. A. Malinin. St. Petersburg, Iuridicheskii fakul'tet Sankt-Peterburgskogo universiteta Publ.: 43-48. (In Russian)

Kolosov, Yu. M., Krivchikova, E. S. (comp.). 1996. The Acting International Law: in 3 vols. Moscow, Publishing House of the Moscow Independent Institute of International Law.

Morgun, D. O. 2016. "International Criminal Justice Authorities and the African Union: Problems of Cooperation with the International Criminal Court as an Example". Zakon i pravo 10: 92-96. (In Russian)

Sall, Alioune. 2013. L'Affaire Hissène Habré. Paris, L'Harmattan.

Yakovlev, A.M. 1998. "The Convention against Torture". Moskovskii zhurnal mezhdunarodnogo prava. Spetsial'nyi vypusk: 89-92. (In Russian)

Received: July 13, 2018

Accepted: August 27, 2019

Author's information:

Igor S. Marusin — Dr. Sci. in law, professor; intlaw@jurfak.spbu.ru 